\title{
SYNCHRONIZATION OF IMMUNE AND PSYCHIC SYSTEMS ASSOCIATED WITH SOCIAL STRESS
}

\author{
Evgeniy Dotsenko, ${ }^{a}$ Marya Bogdanova, ${ }^{a}$ Tatyana Fisher, ${ }^{b}$ Sergey Petrov, ${ }^{b}$ Yuri Suhovey, \\ ${ }^{a}$ The Tyumen state university, ${ }^{b}$ The Tyumen centre of science of the Siberian Branch of the Russian \\ Academy of Science, ${ }^{\mathrm{c}}$ Scientific research institute of clinical immunology of the Siberian Branch \\ Russian Academies of Medical Science,_tumiki@mail.ru
}

The article is devoted to the research of the synchronization of immune and psychic systems providing multilayer (functional) protection in accordance with the identically developed strategies. We have discussed evolution interaction of the systems with the following references: mentality in macroworld and immune system in microworld. Their functional isomorphism maintains the dynamic homeostasis according to the principle of reciprocal control, and during their functioning systems presents not the amount of separate parts but "the whole range of events" effect.

UDC Classification Numbers: 159.91, DOI: 10.12955/cbup.2013.53

Keywords: immune system, psychic system, depressive-like condition, laboratory animals

\section{Introduction}

Psychic and immune system do the common task to maintain dynamic homeostasis. It is required for regular vital functions. The reason to couple mentality and immune system is necessity to prepare a living being for functioning in the nearest or distant future; and provide their survival and development both at microworld and macroworld levels.

\section{Synchronization of immune and psychic systems associated with social stress}

Linear depressive-like animals are considered for the analysis to obtain the results. The method of paired distant sensor has been used to form submissive behavior. Every day, at the same time, the dividing wall was removed for ten minutes. This action resulted in aggressive interaction of partners (Kudryavtseva \& Bakshtanovskaya, 1991). Two stages were defined on the basis of period of the experiment. The first stage (named "depression forming stage") begins after 10 days of contact. The other stage (explicit depression stage) begins after 24 days of contact.

\section{Behavioral compensation of depression-like state}

It has been specified that the mice, with pronounced depression-like behavior, show $85 \%$ of freezing behavior (catalepsy) (Tikhonova, 2006). A decrease of their physical activity ( $<<0.001$ ) was found. The exploratory activity $(\mathrm{p}<0.05)$ in the "open field" was tested and the increase of catalepsy time $(p<0.001)$, in the forced swimming test, were shown (Bazovkina, 2005). 
Catalepsy or freezing behavior is a natural form of passive-defensive behavior (passive form of defense). It specifies evolutionally early forms of behavior and associates with expressed neurochemical and physiological changes. In catalepsy, the decrease of sensitivity to extrinsic stimuli as well as to subjective one is observed, which is connected with endogenous movement slowdown at definite excitatory, with intensive concentration.

Therefore, catalepsy and the decrease of behavioral reactions can be considered as functionally directed reaction of psychic that helps minimize environmental risks. The need for releasing excessive psychic tension results in decreasing of external contacts. This strategy can be considered as the passive form of generalized defense, where catalepsy (masking) is used as the somatic or behavior feature that helps to increase the possibility to be indistinguishable under stress factor influence. Behavioral reactions reduction implements different types of avoiding the realities of life: distance increase, ignoring, ability to change sense perception of the situation or its evaluation (threat discrediting), perceptive defense (functional blindness). Since focusing on the new unusual reality results in resources draining, limitation of movements and decreasing of organism work volume evolutionary means minimizing the whole somatic and psychic resources exhaustion.

\section{"Humoral duplication" of behavioural depression at the system level}

The analysis of immune response of the line C57B1/6J mice with conditioned conformation behavior formed in social confrontations has showed decrease of number IgM-AOK $(\mathrm{p}<0.001)$ (Idova, 2011), testosterone and brain dopaminergic brain activity (Akxeenko et al., 1998), as compared with animals without confrontation experience.

According to the data given, it is supposed that brain reaction directed to macroworld risks decrease and expressed with depression-like state are doubled and supported with the immune system changes. Such immune system strategy corresponds to behavioral strategy of activity reduction. It can be defined as the native basic defense - increase of distance from aggressors (withdrawal, escape). From the part of psychic it is expressed with depression, from the part of immune system - with immunesuppression, which confirms the opinion that psychic and immune systems are immanent essentially and isomorphic functionally (Sukhovey \& Dotsenko, 2012).

Immune system response has resulted in work change of nervous and endocrine systems. It can be traditionally estimated as the consumption for the immune response is significant and it influences the other physiological systems. Such effect can be provided by endocrine system - the function of which is to regulate energy processes directed to homeostatic balance support (Shoelson et al., 2006). However, it remains uncertain that evolutional meaning of this consumable reaction is similar to attack or aggression strategy. Immune system response has resulted in nervous and endocrine systems work change. It can be traditionally estimated as the consumption for the immune response is significant and it influences the other physiological systems. Such effect can be provided by endocrine system - the function of which is to regulate energy processes directed to homeostatic balance support (Shoelson et al., 2006). However, it remains uncertain that evolutional meaning of this consumable reaction is similar to attack or aggression strategy.

The alternative explanation is that evolutional meaning of immune and endocrine systems changes consists in behavioral strategy support. Behavior is the level at which survival of an animal critically depends on its life competence. This level is the area of psychic responsibility. In their turn psychic and immune systems function via multiple physiological mechanisms, where interaction with micro 
(macro) world is performed with differentiate neurochemical systems implementing nervous system activity. These systems are as complex as of brain structures. This function is defined by the presence of common mediators and receptors interacting with it (Abramov, 2004).

So, taking into consideration direct involvement of brain in immune response modulation, psychic organ can be considered as one of immunocompetent organs. Nervous and endocrine systems seem to play rather important role. These systems are aimed at providing good coherent and continuous work of the integrating systems ensuring environmental orientation according to their sensor specification: psychic - in macroworld and immune system - in microworld (Sukhovey \& Dotsenko, 2012). It is consistent with the statement that brain and immune systems are functionally isomorphic in their sensor functions: set of programme (universal) necessary for contacts of microworld with macroworld organized structures.

\section{"Cell duplication" of social damage}

Based on an experiment with depression-like state in C57B1/6J mice, we have found out that after confrontations, number of bone marrow suppressors CD8+ increased in 10 days while the number of helpers $(\mathrm{CD} 4+)$ remains unchanged as compared to the control.

After 20-day confrontations the number of (CD8+) has increased not only in the control group but also in the group with 10-day confrontations (Idova et al., 2000). The data are confirmed by the experiment where the number of $(\mathrm{CD} 8+)$ in peripheral blood has been decreased during 2 hours in rats which suffered defeat (Stefanski et al., 1996).

Thus, more the influence of intensive stress is, more immediate immune system reactions are, which mainly depends on the character of these reactions whereas main defense actions are cell resources mobility and flexibility. So, (CD8+) decrease in animal peripheral blood can be seen during the first hours after threat from macroworld. Their (CD8+) increase in bone marrow happens under long stress influence. It means that immune response time helps weaken or stop aggressor influence due to cell material redistribution. When making comparison between psychic and immune-cell strategies it is possible to find definite analogy in main basic natural defenses in their active forms - control, handling and removal. According to Kudryatseva et al. (1991), the level of corticosteroids in blood of submissive animals increased after 20 day confrontation the numbe of CD08+ has increased while testosterone levels decreased. So it is possible to suppose that all these changes can be the consequences of predomination of imunosupressive influence for which brain glucocorticoids and serotonin are responsible.

So, psychic and immune systems have evolutionally developed similar in their working mechanism regulatory (sub) systems and behavior patterns. They provide multilayer defense and develop new strategies capable of defense the body against overloading and damages. The other leading systems which are in close contact with the systems help them. It confirms our thesis that body psychosomatic regulation is performed via immune-neuroendocrine regulation, i.e. via regulatory meta-system where functional state of one system modulates the state of the other system.

\section{Behavioral depression compensation at the organ level}

After 20 days of social defeat of subjected animals (C57B1/6J) some changes in the immune system immunocompetent organs have been observed. CD3+, CD4+, CD8+ $(p<0.05)$ decrease has been 
observed in the thymus gland. The decrease of the absolute number of CD3+ and CD8 $+(p<0.05)$ and increase of percent of CD4+ and CD25+ $(\mathrm{p}<0.05)$ in the spleen and increase of absolute number of CD8 + cell $(p<0.05)$ in the lymph glands have been observed as compared with intact animals (Tenditnik et al., 2004). There is the opinion that cells transition from the thymus, spleen, lymph glands can be determined by the brain neurochemic balance shift towards the prevalence of serotoninergic system activity as its activation is followed by T-lymphocytes activity decreasing (Roman et al., 2002). In its turn, increase (CD4+ and CD25+) in the spleen, (CD8+) in the lymph glands is considered as local immune reactions activation as a response to skin damage occurred under serotonin action (Laberge et al., 1996).

Hence, redistribution of cell resources is favorable not only for the immune system but also for the whole body occurs at the organ level. Organs with the higher level of organization must be able to execute resource manoeuvre level, i.e. at the organ level effectiveness and quality of functioning is controlled, the work of underlying (sub) systems is organized. They are controlled via regulation and communication feedback. It confirms the thesis that integrating systems (psychic and immune system) are body complementary systems which mutually help each other and are synchronized in their activity. Their exact mutual compossibility provides more complete idea than each system individually can do.

\section{Conclusion}

The results of the study show that both of the mental and immune systems are influenced by social stress. These systems, while performing their major functions, present effect of "the whole range of events" and they do not take into account the amount of separate elements. Their functional isomorphism supports dynamic homeostasis under the principle of mutual regulation. This regulation is provided by the complexity of mutually connected and doubling mechanisms, which indicates the possibility of compensation of the system elements' deficiency and excessive activation.

\section{References}

Abramov, V. V. (2004). Basics of immunology. Academiae Scientiarum terrae, No. 1.

Akxeenko, O. V. (1998). Pars D1 et D2 dopamine receptores, in cerebro in incremento exanimationes incidamus inducitur per socialis confrontationes in mures [Pars D1 and D2 dopamine receptors in the brain in the development of depression in rats induced by the social confrontations]. Jurnal vuschey nervnoy deyatelnost, No. 6.

Bazovkina, D. V. (2005). Selectionem pro inclinatio ad catalepsis auget depressive-amo Lineamenta in mures. Inclinatio Selectionem ad catalepsis pro-love auget depressive lineamenta in mures [Seizure selection for the trend to increased depressive-like traits in mice. Seizure for selection to the trend increases the Jupiter-depressive traits in mice]. Genetika, No. 9.

Idova, G. V. (2000). Vliyanie submisivnogo I agresivnogo tipov povedenya na ismenenie chisla Tlymphositov CD4+ i CD8+ of kostnom mozge. [Effect submisivnogo and aggressive behaviors to modify the number of T lymphocytes CD4 + and CD8 + in the bone marrow]. Immunology, No. 1.

Idova, G. V. (2011). Immunology otvet pri aktivacii pre- i postsinaptichexich serotoninovuch 5-HT reseptorov of muchey linii $\mathrm{C} 57 \mathrm{BL} / 6 \mathrm{~J}$ na razlichnuh stadiach rasvitya depresivno-

podobnogo sosnjyaniya. [The immune response is activated pre-and postsynaptic serotonin 5-HT - 
receptors in C57BL/6J mice at various stages of development of depressive-like state]. Bulleten eksperimentalnoy biology i medicin, No. 3.

Kudryavtseva, N. N. \& Bakshtanovskaya, I. V. (1991). Neyrohimichexyi control agresii i podchinenya [The neurochemical control of aggression and submission]. Jurnal vuschey nervnoy deyatelnosti, No. 5 .

Tikhonova, M. A. (2006). Effectus imipramine dum actibus et cerebri V-HT 1A serotonin receptor in mures genere praedisposito, ad catalepsis [Imipramine effects on behavior and brain serotonin 5-HT $1 \mathrm{~A}$ receptor in mice genetically predisposed to seizure]. Bulleten eksperimentalnoy biology i medicini, No. 1. http://dx.doi.org/10.1007/s10517-006-0090-7

Tenditnik, M. V., Shurlygina, A.V., Melnikova, E.V., Kudryavtseva, N.N. \& Trufakin V.A. (2004). Ismenenie subpopulyacionnogo sostava lymfocitov immunokompetentnuch organov muchey pod vliyaniem chroniceskogo socyalnogo stressa. [Change of subpopulation structure of lymphocytes of immunocompetent bodies of mice under the influence of a chronic social stress]. Rossyixyi fisiologicexiy jurnal immeni I.M. Secenova, No. 12.

Sukhovey, Y. G. \& Dotsenko, E. L. (2012). Immanentnost i isomorfnost psihyki i immunoy systém [Immanentism and isomorphism of psyche and immune system]. Vestnik uralxoy medicinxoy akademichexoy nauky, No. 4.

Long, K. Z. \& Nahthakumar, N. (2004). Energetic and nutritional regulation of the adaptive immune response and trade-offs in ecolodgical immunolodgy. Am. J. Hum. Biol., Vol. 394.

Kudryavseva, N. N., Bakshtanovskaya, I. V. \& Koryakina, L. A . (1991). Social model of depression in mice of C57Bl/6J strain. Pharmacol. Biochem. Behav ., No. 38.

Fano, E. \& Sanchex-Martin, J. (2001). Social stress paradigms in male mice: variations in behavior, stress and immunology. Physiol. Behav., No. 73.

Shoelson, S. E., Jongsoon, L. \& Goldfine B. A. (2006). Inflammation and insulin resistance. J. Clin. Invest., No. 4.

Stefanski, V., Salomonis, G. F., Kling, A. S., Thomam, J. \& Plaeger. S. (1996). Effect on rat Social confrontation CD4 T cells bearing various isoforms of CD45R. Behav. Immun., 10 (4), 364-79. http://dx.doi.org/10.1006/brbi.1996.0032

Roman, A., Vetulani, J. \& Nalepa, I. (2002). Effect of combined treatment with paroxetine and transcranial magnetic stimulation (TMS) on the mitogen-induced proliferative response of rat lymphocytes. Pol. J. Pharmaco, Vol. 54, No. 6, p. 633-694. 